1988

\title{
Immunochemical and biochemical comparisons between embryonic chick bone marrow and epiphyseal cartilage chondroitin/dermatan sulphate proteoglycans
}

J M Sorrell

F Mahmoodian

B Caterson

Follow this and additional works at: https://researchrepository.wvu.edu/faculty_publications

\section{Digital Commons Citation}

Sorrell, J M; Mahmoodian, F; and Caterson, B, "Immunochemical and biochemical comparisons between embryonic chick bone marrow and epiphyseal cartilage chondroitin/dermatan sulphate proteoglycans" (1988). Faculty Scholarship. 190.

https://researchrepository.wvu.edu/faculty_publications/190 


\title{
Immunochemical and biochemical comparisons between embryonic chick bone marrow and epiphyseal cartilage chondroitin/dermatan sulphate
} proteoglycans

\author{
J. MICHAEL SORRELL ${ }^{1, *}$, FATEMEH MAHMOODIAN ${ }^{2}$ and BRUCE CATERSON ${ }^{2}$ \\ Departments of 'Anatomy and ${ }^{2}$ Biochemstry, School of Medicme, Ilest Linginia Unversity, Morgantoun, IIT'26506, USA \\ * Author for correspondence
}

\begin{abstract}
Summary
Chrondroitin sulphate proteoglycans obtained from embryonic chick bone marrow and epiphyseal cartilage were compared using immunochemical and biochemical analyses. Proteoglycans from each tissue, separated on $\mathrm{CsCl}$ density gradients, under dissociative conditions, into high $\left(1.6 \mathrm{~g} \mathrm{ml}^{-1}\right)$, me$\operatorname{dium}\left(1.5 \mathrm{~g} \mathrm{ml}^{-1}\right)$ and low $\left(1.4 \mathrm{~g} \mathrm{ml}^{-1}\right)$ buoyant density fractions, were immunochemically analysed, using a panel of monoclonal antibodies that specifically recognize chondroitin 4-/dermatan sulphates, chondroitin 6-sulphate, keratan sulphate, the hyaluronate binding region present on connective tissue proteoglycans, and link protein. The same antibodies were used in Western blot analyses to detect intact proteoglycan monomers and core proteins that had been fractionated by agarose-polyacrylamide and by sodium dodecyl sulphate-polyacrylamide gel electrophoresis. Specific differences between marrow and cartilage proteoglycans were detected. In $\mathrm{CsCl}$ gradients, marrow proteoglycans displayed a higher degree of heterogeneity in terms of buoyant densities and hexuronate distribution.
\end{abstract}

Keratan sulphate chains were constituents of the majority of 'large' proteoglycans in the marrow; however, a portion of the large proteoglycans in marrow middle buoyant density fraction either lacked keratan sulphate chains or were substituted with a form different from that found on cartilage proteoglycans. Marrow lacked 'small' chondroitin/ dermatan sulphate proteoglycans that were present in cartilage and contained a more heterogeneous population of proteoglycans, particularly in the lower buoyant density fractions. Both marrow and cartilage were similar in that they contained, as their major components, large, aggregating proteoglycans and link proteins that were immunochemically and biochemically identical. The significance of these differences between marrow and cartilage proteoglycans remains to be determined, but they may, in part, be responsible for imparting unique characteristics to the haematopoietic extracellular matrices.

Key words: proteoglycans, marrow, cartılage.

\section{Introduction}

The concept of a haematopoietic inductive microenvironment was first postulated by Trentin and his colleagues (Curry \& Trentin, 1967; Curry et al. 1967; Trentin, 1978). Since then, it has become increasingly evident that non-haematopoietic stromal cells are largely responsible for generatıng this environment (Dexter, 1982). Stromal cells appear, in large part, to be responsible for elaborating an extracellular matrix milieu that may be critical for haematopoietic-stromal cell interactions (Spooncer et al. 1983; Zuckerman \& Wicha, 1983; Zipori et al. 1985).

A diverse group of molecules, proteoglycans (Hascall \& Hascall, 1981; Hassell et al. 1986), are a major component of hematopoietic extracellular matrices. The

Journal of Cell Science 91, 81-90 (1988)

Printed in Great Britan (C) The Company of Biologists Limited 1988 amounts and relative compositions of these proteoglycans have been shown to vary according to haematopoietic status (Noordegraaf \& Ploemacher, 1979; Noordegraaf \& Ploemacher, 1980; Noordegraaf et al. 1981). Gallagher et al. (1983) provided clear evidence for differences between proteoglycans associated with stromal cells and proteoglycans released into the medium in long-term haematopoietic cultures. Cell-associated proteoglycans were enriched in heparan sulphate and also contained some chondroitin sulphate, whereas those released into the medium consisted almost entirely of chondroitin sulphates. This work was confirmed and extended by Wight et al. (1986), who have also provided important information concerning the nature of intact proteoglycan molecules in haematopoietic cultures. All previous 
Table 1. Monoclonal antibodies used for this study and their epitopes

\begin{tabular}{|c|c|c|}
\hline Antibody & Epitope & Reference \\
\hline $2 \mathrm{~B} 6$ & $\begin{array}{l}\text { Delta-unsaturated 4-sulphated epitope generated by chondroitinase } \\
\text { ABC digestion of chondroitin } 4 \text {-/dermatan sulphates }\end{array}$ & Caterson el al. (1985) \\
\hline $3 \mathrm{~B} 3$ & $\begin{array}{l}\text { Delta-unsaturated 6-sulphated epitope generated by chondrottinase } \\
\text { ABC digestion of chondroitin 6-sulphate }\end{array}$ & Caterson et al. (1985) \\
\hline 5D4 & $\begin{array}{l}\text { Linear, sulphated heptasacchande, or larger, of poly-N'- } \\
\text { acetvllactosamine (keratan sulphate) }\end{array}$ & $\begin{array}{l}\text { Mehmet ef al. (1986; } \\
\text { Caterson et al (1983) }\end{array}$ \\
\hline $1 \mathrm{C} 6$ & $\begin{array}{l}\text { Hyaluronate bindıng region of core proteins after reduction and } \\
\text { alkylation }\end{array}$ & Caterson et al. (1986) \\
\hline $8 \mathrm{~A} 4$ & Link protein & Caterson et al. (1986) \\
\hline
\end{tabular}

studies were limited to the nature of the glycosaminoglycan chains.

The importance of studying intact proteoglycan molecules has been emphasized by recent studies that implicate tissue-specific proteoglycans with the ability to sequester growth factors selectively (Okai, 1985; Gordon et al. 1987; Vlodavsky et al. 1987). Sequestration and concentration of growth factors on surfaces of stromal cells would account, in part, for the difficulties in recovering haematopoietic growth factors from long-term marrow cultures (Dexter et al. 1977; Williams et al. 1977) and might, in part, account for the apparent requirement for close cell-to-cell contact between haematopoietic and stromal cells (Dexter, 1982; Bentley, 1981).

In the present study, embryonic chick marrow chondroitin sulphate proteoglycans were characterized and compared with embryonic chick cartilage proteoglycans, about which considerable information has accumulated (Kimata et al. 1974; Vasan \& Lash, 1978; Noro et al. 1983; Shinomura et al. 1983; Carrino \& Caplan, 1985). Well-characterized monoclonal antibodies that specifically recognize chondroitin 4-sulphate and dermatan sulphate (2B6), chondroitin 6-sulphate (3B3), and keratan sulphate (5D4) chains were used to identify GAG chains and to immunolocate proteoglycans on Western blots after composite agarose-polyacrylamide gel electrophoresis of intact monomers and sodium dodecyl sulphate-polyacrylamide gel electrophoresis (SDS-PAGE) analyses of core proteins (Caterson et al. 1983, 1985, 1986, 1987). Monoclonal antibody 1C6, which specifically recognizes the hyaluronate binding region, was used to identify chondroitin sulphate proteoglycans that have the potential to form aggregates (Stevens et al. 1984; Caterson et al. 1986, 1987), while antibody 8 A4 was used to identify link protein (Caterson et al. 1986), also a component of macromolecular aggregates (Hay, 1981). These methods provided a highly sensitive means of examining the total proteoglycan composition of these tissues, not merely the newly synthesized pool obtained after metabolic labelling with radioactive tracers.

A heterogeneous population of marrow chondroitin sulphate proteoglycans was identified, many of which were nearly identical to cartilage proteoglycans. However, comparative studies indicated specific differences in two of the three proteoglycan fractions. These results target chondroitin sulphate proteoglycan species that may be marrow-specific.

\section{Materials and methods}

\section{Antibodies}

All monoclonal antibodies used in these studies had specificities directed aganst different components of chondroitin sulphate proteoglycans. See Table 1 for details concerning epitopes recognized by these monoclonal antibodies.

\section{Extraction and buoyant density fractionation of proteoglycans}

Femora and tibiae were dissected from cold anaesthetized day 17 chick embryos (75 embryos per experiment) and stripped of soft tissue. The epiphyseal cartilages were removed and the bones cut lengthwise in half. Marrow was scraped from the bones directly into cold $4 \mathrm{M}$-guanidine $\cdot \mathrm{HCl}$ containing protease inhibitors (Sajdera \& Hascall, 1969). After all marrow had been removed, excess guanidine $\cdot \mathrm{HCl}$ was added so that the final volume was at least 20 times that of marrow. This was stirred continuously for $24 \mathrm{~h}$ at $4^{\circ} \mathrm{C}$, centrifuged at $15000 \mathrm{~g}$ for $30 \mathrm{~min}$, and the supernatants were collected. Solid $\mathrm{CsCl}$ was added to give a density of $1.5 \mathrm{~g} \mathrm{ml}^{-1}$. After centrifugation at $100000 \mathrm{~g}$ at $10^{\circ} \mathrm{C}$ for $48 \mathrm{~h}$ under 'dissociative' conditions (Oegema el al. 1975), the bottom (MDI or CD1), middle (MD2 or CD2) and top (MD3 or CD3) thirds of the $\mathrm{CsCl}$ density gradients from the marrow or cartilage extracts, respectively, were carefully collected and small samples were taken for density and hexuronate analysis (Carney et al. 1986). Each fraction was dialysed exhaustively against $0 \cdot 15 \mathrm{M} \cdot \mathrm{NaCl}$ and then distilled water. Dry weights were determined and samples stored as lyophilized powder.

\section{Dot-blot analysis}

Marrow and cartilage proteoglycans from each fraction were dissolved in $4 \mathrm{~m}$-guanidine $\mathrm{HCl}, 0.001 \mathrm{M}$-EDTA, $0.1 \mathrm{M}$-Trisacetate, $\mathrm{pH} 8 \cdot 0$, to give a concentration of $1 \mathrm{mg} \mathrm{ml}^{-1}$. Samples were divided in half: one part was treated with $0.065 \mathrm{M}$ dithiothreitol for $4 \mathrm{~h}$ at $50^{\circ} \mathrm{C}$ (reduced), the other part was incubated at $50^{\circ} \mathrm{C}$ without dithiothreitol (native). Both portions were treated with $0.16 \mathrm{M}$-iodoacetic acid in the dark at room temperature for $20 \mathrm{~min}$ then dialysed against three changes of phosphate-buffered saline containing azide (PBS-AZ) over a 24 h period (Stevens et al. 1984).

Native and reduced and alkylated samples were applied by vacuum suction to same sheet of nitrocellulose using a Schleicher and Scheull Minifold apparatus (Caterson et al. 1987). All nitrocellulose sheets were incubated in $5 \%$ bovine serum albumin (BSA) at room temperature for $1 \mathrm{~h}$ and then incubated with 0.01 unit $^{-1}$ of chondroitinase $A B C$ prior to immunolocation. Each monoclonal antibody was diluted 1/100 in $5 \%$ BSA in $0.1 \mathrm{M}$-Tris-saline and was incubated with antigen on nitrocellulose sheets for $90 \mathrm{~min}$ at room temperature. The first antibody incubation step was eliminated for control 
Table 2. Dry weight and hexurnate profiles or proteoglycans obtained from CsCl dissociative gradients

\begin{tabular}{|c|c|c|c|c|}
\hline Fraction & Density & Hexuronate & $\begin{array}{l}\text { \%o Totalt } \\
\text { dry weight }\end{array}$ & $\begin{array}{l}\text { Hexuronate/ } \\
\text { dry weight }\end{array}$ \\
\hline $\begin{array}{r}\text { Marrow } \\
\text { MD3 } \\
\text { MD2 } \\
\text { MD1 }\end{array}$ & $\begin{array}{l}1 \cdot 4 \\
1.5 \\
1.6\end{array}$ & $\begin{array}{l}16 \\
28 \\
56\end{array}$ & $\begin{array}{l}68 \\
16 \\
16\end{array}$ & $\begin{array}{l}0 \cdot 022 \\
0 \cdot 166 \\
0 \cdot 281\end{array}$ \\
\hline $\begin{array}{c}\text { Cartilage } \\
\text { CD3 } \\
\text { CD2 } \\
\text { CD1 }\end{array}$ & $\begin{array}{l}1 \cdot 4 \\
1 \cdot 5 \\
1 \cdot 6\end{array}$ & $\begin{array}{r}7 \\
18 \\
75\end{array}$ & $\begin{array}{l}28 \\
16 \\
56\end{array}$ & $\begin{array}{l}0.039 \\
0.235 \\
0.273\end{array}$ \\
\hline
\end{tabular}

All data represent the averages obtained from three separate fractionation procedures.

- Density is expressed in units of $\mathrm{g} \mathrm{ml}$ !.

† Hexuronate was determined by the method of Bitter \& Muir (1962)

f Dry weights were determined after lyophilization.

$\S$ The hexuronate content of each fraction expressed in mg was divided by the dry weight of each fraction expressed in mg.

samples. After washing three times with Tris-saline, peroxidase-conjugated goat anti-mouse second antibody diluted $1 / 500$ was incubated with each sheet. After washing with Tris-saline, 4-chloro-1-naphthol and $\mathrm{H}_{2} \mathrm{O}_{2}$ substrate was added and coloured precipitating products developed. The reaction was stopped by washing with PBS-AZ. The nitrocellulose sheets were air-dried prior to photographic reproduction.

\section{Fractionation of intact proteoglycan monomers on composite agarose-polyacrylamide gels}

Composite agarose-polyacrylamide gels were run using a modified method described by Carney et al. (1986). Agarose (0.6\% final concentration) was suspended in gel buffer $(0.04 \mathrm{M}$ Tris-acetate $/ 0.001 \mathrm{M}-\mathrm{Na}_{2} \mathrm{SO}_{4}, \mathrm{pH} 6.8$ ) and heated to $90^{\circ} \mathrm{C}$ with constant stirring. This mixture was allowed to cool to $50^{\circ} \mathrm{C}$ before adding acrylamide/bisacrylamide (1.2\% final concentration). The final mixture was poured into preheated $\left(50^{\circ} \mathrm{C}\right)$ slab gel plates and allowed to set at $4^{\circ} \mathrm{C}$ for $1 \mathrm{~h}$. Plates were cquilibrated overnight in $4 \mathrm{M}$-urea and gel buffer (Carney et al. 1986). Samples dissolved in $8 \mathrm{M}$-urea were applied to the gel and electrophoresed at constant voltage for $2 \mathrm{~h}$ until the tracking dye had migrated $3-4 \mathrm{~cm}$. Some gels were stained with $0.02 \%$ Toluidine Blue to reveal proteoglycans. Samples from other gels were immunolocated after transfer onto nitrocellulose (see dot-blot procedures). Enzyme digestion, when needed, was performed on nitrocellulose-bound samples prior to immunolocation. The first antibody incubation step was omitted for one set of samples as a negative control. All immunolocation studies were performed on parallel set of samples, one digested with chondroitinase $A B C$ while bound to the nitrocellulose, the other remaining undigested. Canine articular cartılage proteoglycan (a gift from S. Carney, Kennedy Institute, London) was used as a standard in these analyses.

\section{Fractionation of proteoglycan core proteins by sodium dodecyl sulphate-polyacrylamide gel electrophoresis}

Lyophilized marrow fractions were dissolved in distilled water to make a $1 \mathrm{mg} \mathrm{m}^{-1}$ solution. Chondroitinase $A B C, 0.05$ unit $\mathrm{ml}^{-1}$ in $0.1 \mathrm{M}$-Tris-acetate, $\mathrm{pH} 8.0$, was added and the samples were incubated for $1 \mathrm{~h}$ at $37^{\circ} \mathrm{C}$. Samples were boiled for $5 \mathrm{~min}$ in the presence of 2-mercaptoethanol. Samples and molecular weight standards were added to 5 or to $7 \%$ to $17 \%$ gradient gels and electrophoresed at $50 \mathrm{~mA} \mathrm{gel}^{-1}$ while samples were in the stacking gel, and thereafter at $35 \mathrm{~mA} \mathrm{gel}^{-1}$. Western blots were blocked and stained as described above (dot-blot assay) using $1 / 100$ mixture of $2 \mathrm{~B} 6$ and $3 \mathrm{~B} 3$ as primary antibodies. As a negative control, the first antibody incubation step was eliminated for one set of samples.

Western blot analysis of link proten was performed as described above, except that antibody $8 \mathrm{~A} 4$ was used for immunolocation after $10 \%$ SDS-PAGE analyses of the ND3 and $\mathrm{CD} 3$ fractions.

\section{Results}

Comparison of marrow and cattilage proteoglycans fractionated on dissociative $\mathrm{CsCl}$ density gradients

Proteoglycan monomers, extracted from the same day 17 embryonic chick femoral and tibial bone marrows and epiphyseal cartilages, were compared using combined immunochemical and biochemical analyses. Proteoglycan monomers from both tissues were fractionated on $\mathrm{CsCl}$ density gradients under dissociative conditions and three equal portions were collected ('Table 2). Marrow proteoglycans differed from cartilage proteoglycans in that a substantially lower proportion of the total hexuronate (56\% for MD1 versus $75 \%$ for $\mathrm{CD} 1$ ) was found in the high buoyant density (D1) fractions and correspondingly higher proportions of hexuronate were found in the lower buoyant density fractions, MD2 and MD3. Marrow contained a substantially higher proportion of extractable material that partitioned to the low buoyant density fraction ( $68 \%$ dry weight compared to $28 \%$ dry weight, Table 2), indicating that marrow contaned a higher content of non-proteoglycan molecules than did cartılage. Both D1 fractions were identical in terms of their hexuronate to dry weight ratios and buoyant densities, but the hexuronate to dry weight ratio of marrow fraction MD2 was lower than that of marrow fraction MD1, as well as cartilage fractions CD1 and CD2. This implies that MD2 proteoglycans were probably substituted with either fewer or shorter GAG chains than those of proteoglycans in all other D1 and D2 fractions. The presence of partially degraded proteoglycans in marrow might also account for this difference.

Immunochemical comparisons of marrow and cartilage proteoglycan monomers

Epitopes recognized by three carbohydrate-specific monoclonal antibodies (Table 1) were found in each marrow and cartilage fraction (Fig. 1). This suggests that 


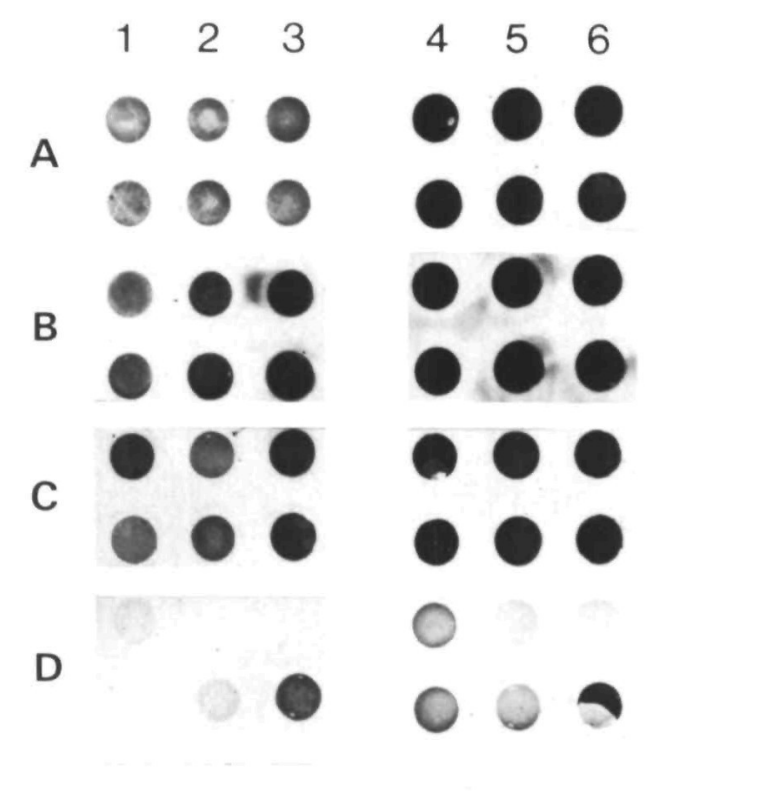

E

Fig. 1. Dot-blot analysis was used to compare marrow MD3 (1), MD2 (2), MD1 (3), CD3 (4), CD2 (5), and CD1 (6) fractions. Samples from each fraction were immunolocated with: A, monoclonal antibody 2B6, specific for chondroitin 4-/dermatan sulphates; B, antibody 3B3, specific for chondroitin 6-sulphate, antibody 5D4; C, specific for keratan sulphate; D, antibody $1 \mathrm{C} 6$, specific for epitopes associated with hyaluronate binding region, and, as a control; E, no first antibody. Antigen in the top rows of each panel were unreduced, while proteoglycans in the bottom rows were reduced and alkylated prior to immunoanalyses.

some degree of heterogeneity existed in proteoglycan populations from both marrow and cartilage. However, these analyses did not indicate to what extent chondroitin 4-/dermatan sulphate chains, recognized by antibody $2 \mathrm{~B} 6$, or chondroitin 6-sulphate chains, recognized by antibody $3 \mathrm{~B} 3$, were substituted to the same or to different core proteins. Other evidence for differential glycosaminoglycan chain substitution is presented below (section III). Keratan sulphate epitopes, which must be sulphated, were identified using antibody 5D4 (Mehmet et al. 1986). These epitopes were present in all fractions from both marrow and cartilage, although the marrow middle buoyant density fraction (MD2) appeared to contain relatively less of this epitope than did any of the other fractions (Fig. 1). This indicates that proteoglycans obtained from bone marrow were more cartilage-like than expected.

Also shown in Table 1 are the results obtained using a monoclonal antibody that recognizes a specific region of core proteins, the hyaluronate binding region. Reduction and alkylation is required to denature the core protein and to expose the epitope to antibody $1 \mathrm{C} 6$. This antibody identified epitopes in both marrow and cartilage D1 fractions (Fig. 1). However, on the basis of the relative intensity of dots after immunolocation, it appeared that

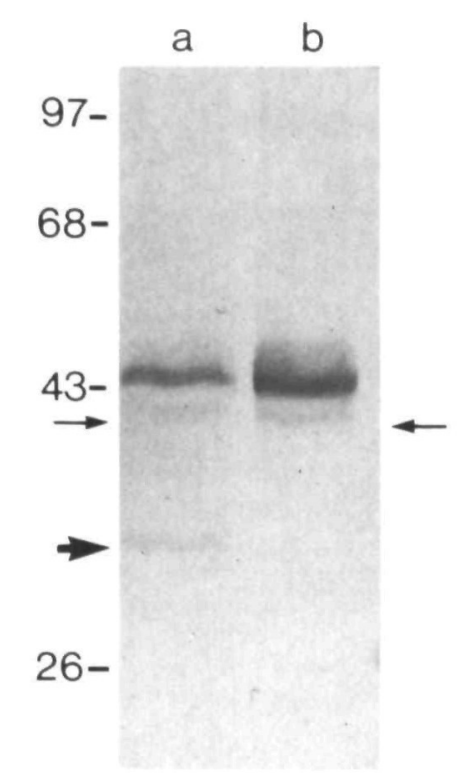

Fig. 2. Samples from low buoyant density marrow and cartilage fractions were analysed by SDS-PAGE, under reducing conditions, on a $10 \%$ gel, electroblotted onto nitrocellulose, and immunolocated using antibody $8 \mathrm{~A} 4$, specific for link protein. One major band, representing a protein with an apparent molecular weight of $43 \times 10^{3}$, was immunolocated in both marrow (lane a) and cartilage (lane b) fractions. Also, a second band, probably representing a second and minor link protein, was weakly immunolocated (thin arrows) in each fraction. Marrow (lane a) contained a faster migrating peptide (thick arrow), which was also immunolocated by antibody $8 \mathrm{~A} 4$.

cartılage contained a higher proportion of proteoglycans with a hyaluronate binding region. Quantitative studies will be needed to confirm this observation. In cartilage, fractions from all buoyant densities contained the epitopes associated with the hyaluronate binding region. In marrow, this epitope was primarily found in the MDI fraction, while some epitope (but at much lower levels than found in cartilage) was detected in the MD2 fraction, and almost no epitope was found in the MD3 fraction. Immunolocation by antibody $1 \mathrm{C} 6$ of components in the unreduced proteoglycan samples from the cartilage low buoyant density fraction (CD3) could be attributed to the presence of either proteolytically cleaved and/or otherwise denatured components of the hyaluronate binding region (Caterson et al. 1986).

Low buoyant density fractions from both marrow and cartilage contained one major link protein, as identified by link protein-specific antibody $8 \mathrm{~A} 4$ (Fig. 2). This link protein migrated on a $10 \%$ SDS-polyacrylamide gel with an apparent molecular weight of $43 \times 10^{3}$. In addition, a minor, slightly faster migrating link protein was present in both tissues. The marrow fraction contained a faster migrating peptide that was also immunolocated by antibody $8 \mathrm{~A} 4$. These studies were repeated using several different marrow and cartilage samples, comparing the results both with and without mercaptoethanol reduction. The faster migrating peptide was never identified in non-reduced samples, but was identified in some 


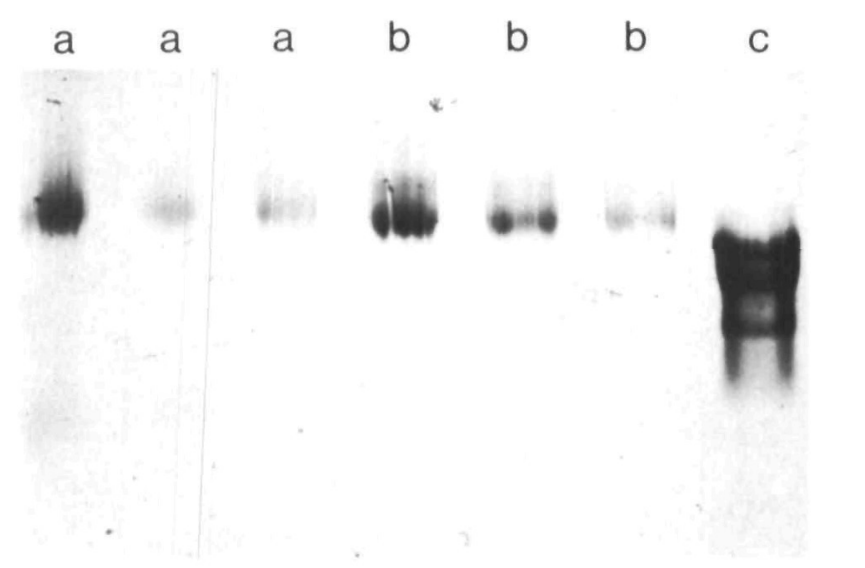

Fig. 3. Serial dilutions of intact proteoglycans from marrow and cartilage fractions MD1 (lanes a), CD1 (lanes b) and, as a standard, canine femoral articular cartilage proteoglycan monomer (lanes c) were analysed by electrophoresis on composite agarose-polyacrylamide gels. The gel was stained with $0.2 \%$ Toluidine Blue.

of the reduced samples. Previously, it had been shown that reduction by mercaptoethanol was needed to identify link protein fragments (Mort et al. 1985). Thus, it is possible that the small peptide is a proteoglycalically cleaved component of intact link protein. Identification of both link protein and hyaluronate binding region is consistent with the presence of aggregating proteoglycans in bone marrow, which are similar to those found in cartilage (Hascall \& Hascall, 1981).

Comparison of intact chondroitin sulphate proteoglycan monomers from marrow and cartilage using composite agarose-polyacrylamide gels

Marrow and cartilage high buoyant density proteoglycans were analysed according to their electrophoretic mobilities in composite agarose-polyacrylamide gels. Using this procedure, the heterogeneous proteoglycan subpopulations can be separated and then analysed biochemically using immunochemical procedures (Carney et al. 1986). In Fig. 3, marrow and cartilage proteoglycans, along with a canine cartilage proteoglycan monomer standard, were identified by staining the gel with Toluidine Blue. Proteoglycans from both chick tissues migrated with similar mobilities that were slower than the canine standard. A slower migration in composite agarose-polyacrylamide gels is usually indicative of large chondroitin sulphate-containing proteoglycans with relatively low amounts of keratan sulphate. In both tissues the proteoglycan bands were diffuse, consistent with a high degree of polydispersity in size and charge.

Electrophoretic analysis on composite agarose-polyacrylamide gels was repeated, but now proteoglycans were identified on Western blots using monoclonal antibodies 2B6 and 3B3 separately (Fig. 4). Chondroitin 6sulphate-specific antibody $3 \mathrm{~B} 3$ identified a slower migrating subpopulation (Fig. 4, lanes a and b). In contrast, antibody 2B6, specific for chondroitin 4-/dermatan sulphates detected a faster migrating subpopulation of proteoglycans in both marrow and cartilage (Fig. 4, lanes $a^{\prime}$ and $\left.b^{\prime}\right)$. These data suggest that at least two subpopu-

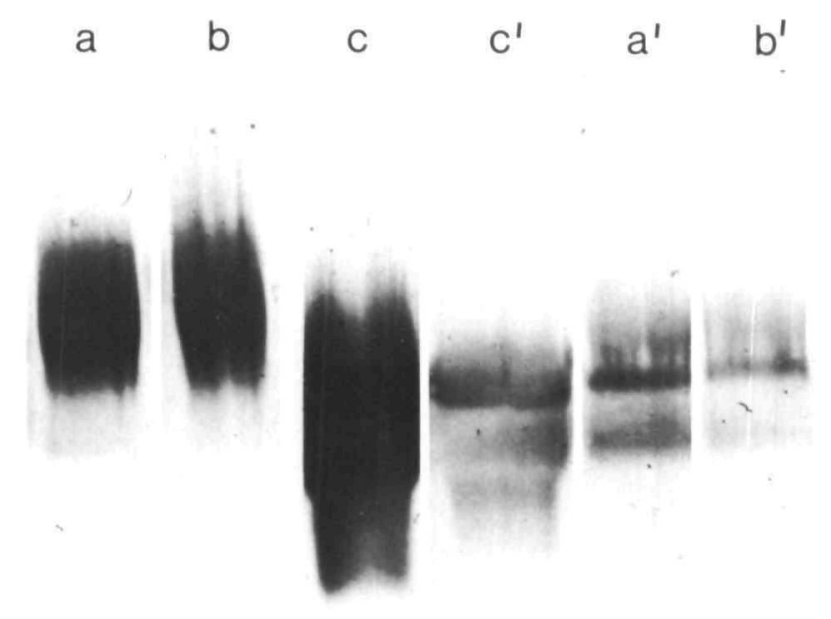

Fig. 4. Intact proteoglycans from marrow and cartilage fractions MD1 (lanes a and $a^{\prime}$ ) and CD1 (lanes b and $b^{\prime}$ ), as well as canine articular cartilage proteoglycans (lanes $c$ and $\left.c^{\prime}\right)$, were analysed by electrophoresis on a composite agarose-polyacrylamide gel, electroblotted onto nitrocellulose, and immunolocated using antibody $3 \mathrm{~B} 3$, antichondroitin 6-sulphate (lanes a, b, c); and antibody 2B6, anti-chondroitin 4-/dermatan sulphates (lanes $a^{\prime}, b^{\prime}, c^{\prime}$ ). The nitrocellulose sheets were incubated with chondroitinase ABC prior to immunolocation with monoclonal antibodies.

lations of proteoglycans were present in the high buoyant density fractions: one subpopulation of proteoglycans substituted largely with chondroitin 4-/dermatan sulphate and a second subpopulation substituted largely with chondroitin 6-sulphate. However, the existence of a population of proteoglycans substituted by multiple types of glycosaminoglycan chains cannot be totally excluded. The migration patterns of the intact monomers suggest that chick D1 proteoglycan monomers are large; however, mobilities can also be affected by ionic charge. In order to confirm that these monomers were in fact large proteoglycans, the sizes of core proteins were determined.

\section{Comparison of marrow and cartilage proteoglycan core proteins by SDS-PAGE after removal of chondroitin sulphate $G A G$ chains by chondroitinase $A B C$}

The core proteins, generated by digestion with chondroitinase $\mathrm{ABC}$, from each marrow and cartilage fraction, were analysed by SDS-PAGE on $5 \%$ slab gels under reducing conditions (Fig. 5). Samples from fractions MD1 (lane a), CD1 (lane b), MD2 (lane c) and CD2 (lane d), detected on a Western blot by a mixture of antibodies $2 \mathrm{~B} 6$ and $3 \mathrm{~B} 3$, remained either in the stacking gel or just entered the top of the running gel, indicating that they were large molecules with apparent molecular weights in excess of $212 \times 10^{3}$ (Fig. 5). This means that all proteoglycan fractions analysed on this gel have large core proteins and can be considered as belonging to the class of large proteoglycans (Heinegard et al. 1985; Hassell et al. 1986). It was not possible, on the basis of these results, to determine whether these large proteoglycans found in marrow and cartilage were exactly equivalent in size, 


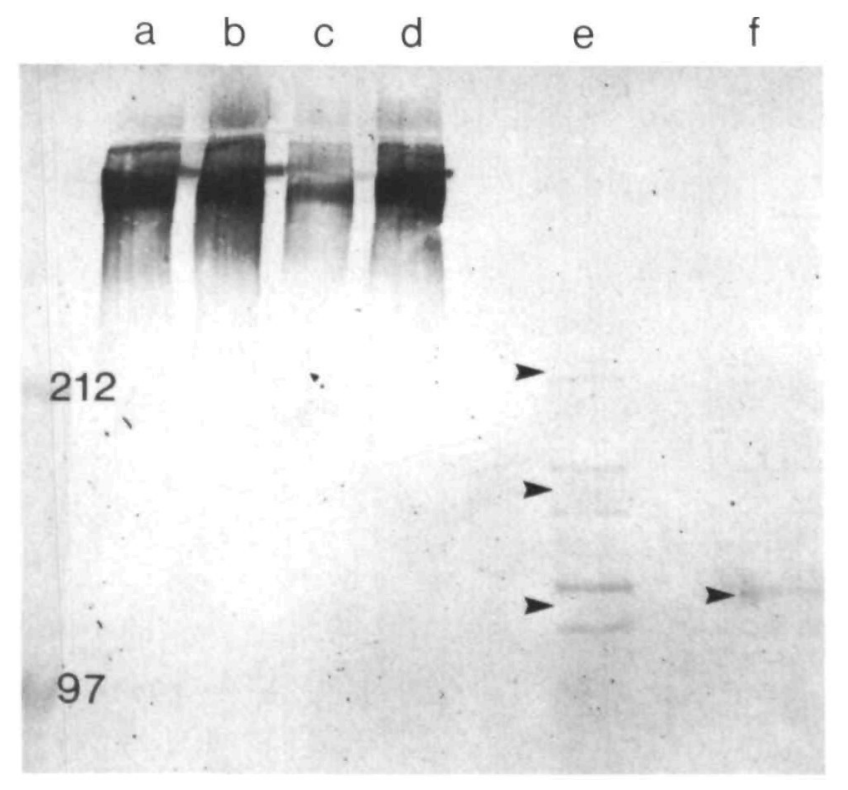

Fig. 5. Proteoglycan core protein derived from chondroitinase $\mathrm{ABC}$-digested marrow and cartilage fractions MD1 (lane a), CD1 (lane b), MD2 (lane c), CD2 (lane d), MD3 (lane e), and CD3 (lane f) were analysed by SDS-PAGE on a $5 \%$ gel, electroblotted onto nitrocellulose, and immunolocated with a mixture of monoclonal antibodies $2 \mathrm{~B} 6$ and 3B3. Nolecular weight markers for 212 and $97\left(\times 10^{3}\right), U_{\mathrm{r}}$ are indicated. Arrowheads in lane e indicate three pairs of bands immunodetected in the MD3 fraction, while the arrowhead in lane $f$ indicates the single band immunodetected in the CD3 fraction.

since these molecules were not effectively resolved in the running gel. Small proteoglycan core proteins with apparent molecular weights of 43 and $47\left(\times 10^{3}\right)$ were also immunochemically identified in cartilage D2 fractions after electrophoresis on a $7 \%$ to $17 \%$ linear gradient SDS-polyacrylamide gel, but similar core proteins were not detected in the equivalent marrow fraction (Fig. 6A,B), thus indicating a difference in the proteoglycan compositions of these two tissues.

Intermediate-sized core proteins, migrating with apparent molecular weights ranging from 100 to $200\left(\times 10^{3}\right)$, were detected on a Western blot using a mixture of antibodies 2B6 and 3B3 (Fig. 5, lanes e and f). Multiple bands were detected in the marrow fraction MD3 (lane e). In contrast, only one such band, with an apparent molecular weight of $120 \times 10^{3}$ and corresponding to the second fastest migrating MD3 band, was identified in the cartilage fraction CD3 (lane f). It is likely that some or possibly all of the proteoglycan core proteins identified in the low buoyant density fractions represented partial degradation products of large proteoglycans.

Comparative dot-blot immunoanalyses of marrow and cartilage fractions (Fig. 1) revealed the presence of keratan sulphate epitopes, using antibody 5D4, in both marrow and cartilage proteoglycans. As noted above, the MD2 fraction contained relatively less of this epitope than did any other marrow or cartilage fractions. The low level of keratan sulphate substitution of the MD2 fraction was further confirmed on Western blots (Fig. 7). Anti- a

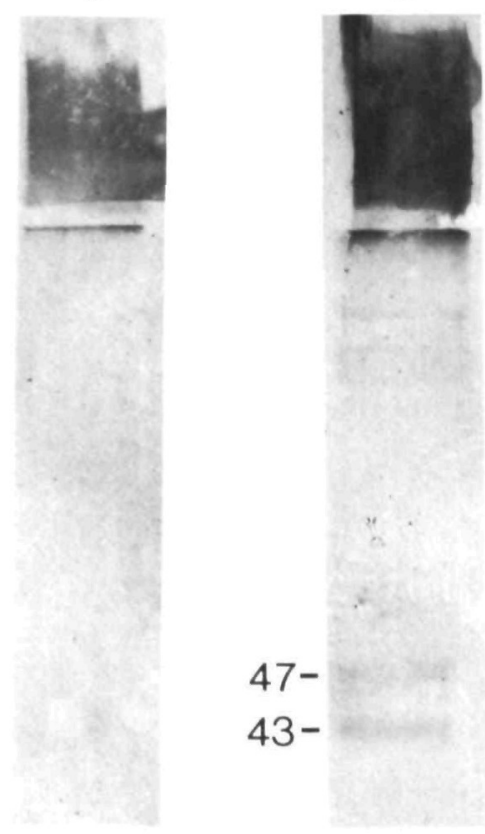

Fig. 6. Proteoglycan core protein derived from chondroitinase $\mathrm{ABC}$-digested marrow and cartilage fractions MD2 (lane a) and CD2 (lane b) were analysed by SDS-PAGE on a $7 \%$ to $17 \%$ linear gradient gel, electroblotted onto nitrocellulose, and immunolocated with a mixture of monoclonal antıbodies $2 \mathrm{~B} 6$ and $3 \mathrm{~B} 3$. Arrowheads indicate 43 and $47\left(\times 10^{3}\right) M_{\mathrm{r}}$ bands in CD2 fractions.

body 5D4 immunolocated epitopes in both marrow (lane a) and cartilage (lane b) high buoyant density fractions, but failed to identify epitopes in the marrow middle density fraction (lane c), although epitopes were identified in the CD2 fraction (lane $\mathrm{d}$ ). The discrepancy

a
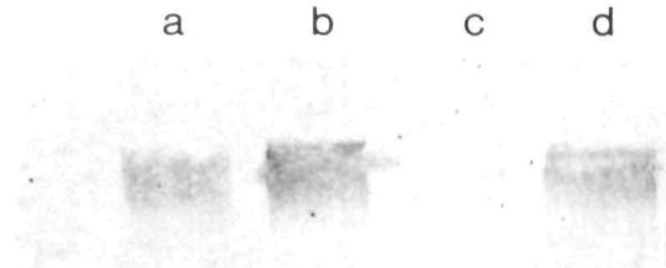

212

Fig. 7. Proteoglycan core protein derived from chondroitinase $\mathrm{ABC}$-digested marrow and cartilage fractions MD1 (lane a), CD1 (lane b), MD2 (lane c), and CD2 (lane d) were analysed by SDS-PAGE on a $5 \%$ gel, electroblotted onto nitrocellulose, and mmunolocated with monoclonal antibody $5 \mathrm{D} 4$, specific for keratan sulphate. The $212 \times 10^{3} \mathrm{M}_{\mathrm{r}}$ marker is indicated. 
between these results and those shown in Fig. 1 are probably related to the lower sensitivity of Western blot analyses compared with that of dot-blot analyses. Repetition of these studies using the same and different keratan sulphate-specific antibodies produced the same results as those indicated above. These results indicate that some of the marrow proteoglycans differ, in terms of their constituent glycosaminoglycan chains, from cartilage proteoglycans.

\section{Discussion}

The present data indicate that, while there was a high degree of similarity between chick marrow and cartilage proteoglycans, diversity also existed. Several specific differences between marrow and cartilage proteoglycans were noted. (1) In marrow, proteoglycan monomers appeared to display a higher degree of heterogeneity. A substantially higher proportion of proteoglycans resided in the middle and low buoyant density fractions. (2) Marrow middle buoyant density proteoglycans were substituted with either less or a different form of keratan sulphate. (3) Small proteoglycans, characteristic of cartilage, bone, and some other non-cartilaginous tissues (Shinomura et al. 1983; Hassell et al. 1986), appeared to be absent from marrow. (4) Finally, marrow contained what appeared to be a heterogeneous population of proteoglycans in the low buoyant density fraction that were not detected in the equivalent cartilage fraction.

Marrow from chick embryos contained large chondroitin sulphate proteoglycan monomers, which possessed large core proteins similar in size to those found in cartilage. Nonetheless, marrow proteoglycans apportioned differently from cartilage proteoglycans on dissociative $\mathrm{CsCl}$ gradients. Marrow contained a substantially higher proportion of intermediate and low buoyant density proteoglycans. This suggested that differences in glycosylation and/or sulphation patterns might have existed between some of the marrow and cartilage proteoglycans. Partial degradation of proteoglycans would also result in smaller sizes and lower buoyant densities. Hence, differences in endogenous turnover of proteoglycan could affect the partitioning of proteoglycans on $\mathrm{CsCl}$ gradients.

A high proportion of marrow proteoglycans were cartilage-like in terms of their large size, presence of an epitope associated with the hyaluronate binding region, and substitution with keratan sulphate. Nevertheless, some of the marrow proteoglycans, particularly those in the MD2 fraction, differed from cartilage proteoglycans in regard to keratan sulphate substitution. Antibody 5D4 provided a weak immunolocalization of MD2 when the more sensitive dot-blot assay was used, and failed to identify epitopes on MD2 on less-sensitive Western blots after SDS-PAGE fractionation. These data suggest that relatively little keratan sulphate was associated with marrow MD2 proteoglycans. Alternatively, they suggest that keratan sulphate, if present, did not contain epitopes that were readily recognized by antibody 5D4. Chemical desulphation of keratan sulphate chains reduced anti- genicity for this antibody (Mehmet et al. 1986; Funderburgh et al. 1987). Thus, low sulphated keratan sulphate might be present on some marrow proteoglycans, particularly those in the MD2 fraction, and this might account for the weak immunochemical reactivity of antibody 5D4. Marrow also differed from cartilage in that small chondroitin sulphate proteoglycans were absent, or at least undetected, by the methods used in this study. Small proteoglycans, with core proteins of 43 and $47\left(\times 10^{3}\right) M_{r}$, as assessed by SDS-PAGE, have been identified in cartilages obtained from a variety of vertebrate species, including those from embryonic chicks (Shinomura et al. 1983; Hassell et al. 1986). It was unlikely that this was due to procedural problems, since two core proteins with apparent molecular weights of 43 and $47 \times 10^{3}$ were detected in the CD2 fraction. Small proteoglycans, usually substituted with dermatan sulphate chains, are not entirely restricted to cartilages (Hassell et al. 1986). Wight et al. (1986) identified, as a minor species, a small dermatan sulphate proteoglycan produced by long-term cultures of human marrow. These 'small' proteoglycans, in a variety of tissues, often appear to be closely associated with collagen types I and III (Hassell et al. 1986). The relative sparsity of such collagens in embryonic chick marrow might account for the absence of small proteoglycans in chick marrow (Sorrell et al. 1987).

Marrow, but not cartilage, contained an apparently heterogeneous population of proteoglycans in the low buoyant density fraction. At least six core proteins were detected on Western blots of marrow D3 proteoglycans that had been fractionated by SDS-PAGE. The apparent molecular weights of marrow core proteins ranged from 100 to $200\left(\times 10^{3}\right) M_{\mathrm{r}}$ in marrow, compared to only one core protein, of about $120 \times 10^{3} M_{r}$, in cartilage. These putative, intermediate-sized proteoglycans have yet to be identified definitively. At present two possibilities exist: one or more bands in the MD3 fraction might represent the core protein(s) of a uniquely different proteoglycan; on the other hand, these might be partially degradation products of large core protein(s), those larger than $212 \times 10^{3} M_{\mathrm{r}}$. Both marrow and cartilage proteoglycans were extracted simultaneously in the same media containing protease inhibitors. Multiple bands were absent from the equivalent cartilage fraction (a tentative identification can be made for the one band in the CD3 fraction, see below). Thus, it is unlikely that degradation, if it existed, could be attributed to the extraction procedures. Rather, if degradation occurred, it is more likely to be a consequence of higher endogenous turnover of marrow proteoglycans.

Proteoglycans comprise a diverse group of molecules (Hassell et al. 1986). Nevertheless, this diversity is limited. Therefore, it is not surprising that similarities among marrow and cartilage proteoglycans exist. Wight et al. (1986) also commented on the overall similarity of proteoglycans obtained from long-term human marrow cultures to proteoglycans obtained from aorta, and in this study, similarities among chick marrow and cartilage proteoglycans were clearly evident. As with cartilage, most marrow proteoglycans belong to a family of large 
proteoglycans (Heinegard et al. 1985; Hassell et al. 1986), some of which, particularly those in the high buoyant density fraction, contained a hyaluronate binding region. This implies that these proteoglycans are capable of associating with hyaluronic acid to form macromolecular aggregates (Hascall \& Hascall, 1981). Further evidence for the presence of proteoglycan aggregates was provided by the immunodetection of link protein, also known to be a component of macromolecular aggregates (Hay, 1981). Similar proteoglycans have been identified in a wide variety of non-cartilaginous tissues and cultured fibroblastic cell lines (Norling et al. 1978; McMurtrey et al. 1979; Wagner et al. 1983; Schafer et al. 1984; Heinegard et al. 1985; Hassell et al. 1986). Indirect evidence for proteoglycan aggregates was obtained from histochemical studies of chick marrow where the high iron diamine-silver protemate method was used to stain chondroitinase-ABC-digestible material in the marrow (Sorrell et al. 1987). Digestion of tissue with Streptomyces hyaluronidase, which is known to degrade hyaluronate specifically (Hay, 1981), resulted in the loss of sulphated glycoconjugates, presumably chondroitin sulphates bound to hyaluronate. The presence of hyaluronate in marrow and other haematopoietic tissues is well documented (Olsson, 1971; Taniguchi et al. 1974; Noordegraaf \& Ploemacher, 1979, 1980; Noordegraaf et al. 1981; Wight et al. 1986; Gordon et al. 1987; Oguri et al. 1987). This does not mean that all marrow proteoglycans participate in macromolecular aggregates. On the basis of inferences obtained from dot-blot analyses, the middle and low buoyant density marrow proteoglycans did not contain a hyaluronate binding region and consequently were unlikely to be capable of forming aggregates. If so, this would place the large core protein of the proteoglycans of the middle buoyant density marrow and cartilage fractions in the family of large non-aggregating proteoglycans (Heinegard et al. 1985).

The occurrence of keratan sulphate proteoglycans in marrow was unexpected, since chondroitin sulphate proteoglycans containing keratan sulphate chains have been considered exclusive to cartilage. Keratan sulphate in the extracellular speces of chick marrow also has been identified using immunocytochemical methods at the electron-microscopic level (Sorrell et al. 1988). Recently, keratan sulphate chains have been identified in tissues other than cartilage and cornea. Circumstantial evidence for its presence has been presented for aorta (Heinegard $\&$ Hascall, 1979), and more recent immunocytochemical evidence has been presented for its presence in developing conjunctiva (Sundarraj et al. 1986) and in the corpora amylacea of the human brain (Liu et al. 1987). Funderburgh et al. (1987) have surveyed a variety of bovine and chick non-cartilaginous tissues and have found that keratan sulphate substitution is much more widespread than anticipated. The function of keratan sulphatesubstituted proteoglycans in non-cartilaginous tissues, including marrow, remains to be established.

Only one core protein, with an apparent molecular weight of $120 \times 10^{3}$, was identified in the cartilage low buoyant density fraction. This proteoglycan has yet to be positively identified, but it is possible that it represents
PG-Lt described by Noro et al. (1983), which has subsequently been renamed collagen type IX (Hassell et al. 1986; Irwin \& Mayne, 1986). Huber et al. (1986) have estimated the size of this, minus the chondroitin sulphate chain, at $115 \times 10^{3}$. If the $120 \times 10^{3}$ band proves to be collagen type $\mathrm{IX}$, then it is also probably present in marrow.

The demonstration that there were apparent differences in the composition of chondroitin sulphate proteoglycan between marrow and cartilage may prove to be significant. Chondroitin sulphates have been demonstrated to interact with some types of blood cells, particularly lymphocytes, with a consequent modulation fo some of their cellular functions (Darzynkiewicz \& Balazs, 1971; Siegel et al. 1987). Extracellular matrix and/or components associated with matrix have been shown to promote haematopoiesis either directly or indirectly. Matrix derived from haematopoietic tissues, but not other tissues, promotes the attachment of haematopoietic stromal cells to culture dishes and consequently promotes growth and differentiation of haematopoietic cells (Campbell et al. 1985). Similarly, bone marrow matrix has been shown to alter the phenotypic expression of HL-60 cells (Luikart et al. 1987). It is possible that these functions are, at least in part, mediated by the apparent ability of extracellular matrix components, particularly proteoglycans, to sequester haematopoietic growth factors (Okai, 1985; Gordon et al. 1987). The implication to be drawn from these studies is that haematopoietic-specific matrix components, probably proteoglycans, may be involved in regulating haematopoiesis. If so, it should be possible to identify those proteoglycans. The present study provides evidence that some marrow chondroitin sulphate proteoglycans differ from those found in cartilage. Whether these proteoglycans in marrow have functional roles in haematopoiesis remains to be determined.

This work was supported by NIH grants CA40059 and AR32666.

\section{References}

BeNtley, S. A. (1981). Close range cell: cell interaction required for stem cell mantenance in continuous bone marrow culture. Expl Hemat 9, 308-312.

Brtter, T. \& Muir, H. M. (1962). A modified uronic acid carbazole reaction. Analyt. Biochem. 4, 330-334.

Campbell, A., Wicha, M. S. \& Long, M. (1985). Extracellular matrix promotes the growth and differcntiation of murunc hematopoietic cells in vitro. $\mathcal{F}$. clin. Ineest. 75, 2085-2090.

Carney, S. L., Bayliss, M. T., Collier, J. M. \& Muir, H. (1986). Electrophoresis of ${ }^{35} \mathrm{~S}$-labeled proteoglycans on polyacrylamıde-agarose composite gels and their visualization by fluorography. Analyt. Biochem. 156, 38-44.

Carrino, D. A. \& Caplan, A. I. (1985). Isolation and characterization of proteoglycans synthesized in ovo by embryonic chick cartilage and new bone. I biol. Chem. 260, 122-127.

Caterson, B., Calabro, T., Donohue, P. J. \& Jahnke, M. R. (1986). Monoclonal antibodics against cartilage proteoglycan and link protein. In Articular Cartilage Biochemistry (ed. K.

Kuettner), pp. 59-73. New York: Raven Press.

Caterson, B., Calabro, T. \& Hampton, A. (1987). Monoclonal antibodies as probes for elucidating proteoglycans structure and 
function. In Biology of Proteoglycans (ed. R. P. Mecham \& T. N. Wight), pp. 1-26. New York: Academic Press.

Caterson, B., Christner, J. E. \& Baker, J. R. (1983). Identification of a monoclonal antibody that specifically recognizes corneal and skcletal keratan sulfatc. Monoclonal antıbodics to cartilage proteoglycans. 7. biol. Chem. 258, 8848-8854.

Caterson, B., Christner, J. E., Baker, J. R. \& Couchman, J. R. (1985). Production and characterization of monoclonal antibodies directed against connective tissue proteoglycans. Fedn Proc. Fedn Am. Socs exp. Biol. 44, 386-393.

Curry, J. L. \& Trentin, J. J. (1967). Hemopoietic spleen colony studic8. I. Growth and differentiation. Devl Biol. 15, 395-413.

Curry, J. L., Trentin, J. J. \& Wolf, N. (1967). Hemopoietic spleen colony studies. II. Erythropoiesis. Y. exp. Med. 125 703-725.

DakZynkiEwicz, A. \& Balazs, E. (1971). Effect of connective tissuc intercellular matrix on lymphocyte stimulation. I. Suppression by hyaluronic acid. Expl Cell Res. 66, 113-118.

DEXTER, T. M. (1982). Stromal cell associated haemoporesis. F. cell. Physiol. Sitppl. 1, 87-94.

Dexter, T. M., Allen, T. D. \& Lastha, L. G. (1977). Conditions controlling the proliferation of haemopoietic stem cells in vitro. $\mathcal{F}$. cell. Physiol. 91, 335-344.

Funderburgh, J. L., Caterson, B. \& Conrad, G. W. (1987). Distribution of proteoglycans antigenically related to corneal keratan sulfate protcoglycan. 7. biol. Chem. 262, $11634-11640$.

Gallagher, J. T., Spooncer, E. \& Dexter, T. M. (1983). Rolc of the cellular matrix in hacmopoicsis. I. Synthesis of glycosammoglycans by mouse blue marrow cell culture. I. Cell Sci. $63,155-171$

Gordon, M. Y., Riley, G. P., Watt, S. M. \& Greaves, M. F. (1987). Compartmentilization of a haematopoietic growth factor (GM-CSF) by glycosaminoglycans in the bone marrow microcnvironment. Nature, Lond. 326, 403-405.

Hascall, V. C. \& Hascall, G. K. (1981). Proteoglycans. In Biology of the Extracellular Malmx (ed. E. D. Hay), pp. 39-63. New York: Plenum.

Hassell, J. R., Kimura, J. H. \& Hascall, V. C. (1986) Proteoglycan core protein families. A. Rev. Biochem. 55, 539-567.

Hay, E. D. (1981). Extracellular matrix. J. Cell Biol. 91, 2058-233s.

Heinegard, D., Bjorne-Persson, A., Coster, L., Franzen, A.,

Gardell, S., Malmstrom, A., Paulsson, M., Sandfalk, R. \& VOGEL, K. (1985). The core proteins of large and small interststial proteoglycans from various connective tissues form distinct subgroups. Brochem. J. 230, 181-194.

HeINEGARD, D. \& HASCALL, V. C. (1979). Characteristics of the nonaggregating proteoglycans isolated from bovine nasal cartilage. 7. biol. Chem. 254, 927-934

Huber, S., van der Rest, M., Bruckner, P., Rodriguez, E. Winterhalter, K. H. \& VAughan, L. (1986). Identification of the type IX collagen polypeptide chains. The $\alpha 2$ (IX) polypeptide carries the chondroitin sulfate chan(s). I. biol. Chem. 261 , $5965-5968$

IRWIN, M. H. \& MAYNe, R. (1986). Use of monoclonal antibodics to locate the chondrottin sulfate chain(s) in type IX collagen. 9. biol. Chem. 261, 16281-16283.

Kimata, K., Okayama, M., Oohika, A. \& Suzuki, S. (1974). Heterogeneity of protcochondroitin sulfates produced by chondrocytes at different stages of cytodifferentiation. $\%$. biol. Chem. 249, 1646-1653.

liu, H. M., Anderson, K. \& Caterson, B. (1987). Demonstration of a keratan sulfate proteoglycan and a mamose-rich glycoconjugate in corpora amylacea of the brain by inmunocytochemical and lectın-bınding methods. F. Neuminmun. $14,49-60$.

Luikakt, S. D., Sackrison, J. L. \& Maniglia, C. A. (1987). Bone marrow matrix modulation of HL-60 phenotype. Blond 70 , $1119-1123$

McMurtrey, J., Radhakrishnamurthy, B., Dalferes, E. R., Berenson, G. S. \& Gregory, J. D. (1979). Isolation of proteoglycan-hyaluronate complexes from bovine aorta. . biol. Chem. 254, 1621-1626.

Mehmet, H., Scudder, P., Tang, P. W., Hounsell, E. F., Caterson, B. \& Felzi, T. (1986). The antigeme determinants recognized by three monoclonal antibodies to keratan sulphate involve sulphated hepta- or larger oligosaccharides of the poly ( $N$ acetyllactosamme) series. Eur. Y. Brochem. 157, 385-391.

Mort, J. S., Caterson, B., Poole, A. R. \& Roughley, P. J (1985). The origin of human cartilage proteoglycan lunk-protein heterogeneity and fragmentation during agıng. Biochem. 7. 232 , $805-812$.

Noordegraaf, E. M., Erkens-Versluis, E. A. \& Ploemacher, R. E. (1981). Studies of the hemopoietic microenvironments: V. Changes in murine splenic and bone marrow glycosaminoglycans during post irradiation hemoporctic regeneration. Expl Hemat. 9 $326-331$.

Noordegraaf, E. M. \& Ploemacher, R. E. (1979). Studies of the hacmopoietic microenvironment. II. Content of glycosaminoglycans in murine bone marrow and spleen under anaemic and polycythaemic condıtions. Scand. I. Haemat. 22 , 327-332.

Noordegraaf, E. M. \& Ploemacher, R. E. (1980). Studies of the haemopoietic microenvironments. III. Glycosaminoglycan levels in relation to phenylhydrazine-induced erythropoiesis in the mouse liver. Scand. 7. Haemat. 24, 132-156.

Norling, B., Glimelius, B., Westermark, B. \& Wasteson, A. (1978). A chondroitin sulphate proteoglycan from human cultured glial cells aggregates with hyaluronic acid. Bochem. biophys. Res. Commun. 84, 914-921.

Noro, A., Kimata, K., Oike, Y., Shinomura, T., Maeda, N., Yano, S., Takahashi, N. \& Suzuki, S. (1983). Isolation and characterization of a third proteoglycan (PG-Lt) from chick embryo cartılage which contains disulfide-bonded collagenous polypeptide. J. biol. Chem. 258, 9323-9331.

Oegema, T. R., Hascal., V. C. \& DziemiatKowski, D. (1975). Isolation and characterization of proteoglycans from the Swarm rat chondrosarcoma. J. biol. Chem. 250, 6151-6159.

Ogurl, K., Okayama, E., Caterson, B. \& Okayama, M. (1987) Isolation, characterization and localization of glycosaminoglycans in rabbit bone marrow. Blosd 70, 501-510.

OkAl, Y. (1985). Large-molecular-weight thymocyte-actıvating factors in extracellular matrix of SV-40-transformed human embryo fibroblasts. Immun. Lett. 11, 63-68.

OLSSON, I. (1971). Mucopolysaccharides of rabbit bone marrow cells. Expl Cell. Res. 67, 416-426.

Sajdera, S. W. \& Hascall, V. C. (1969). Protein-polysaccharide complex from bovine nasal cartilage. A comparison of low and high extraction procedures. 7. biol. Chem. 244, 77-87.

Schafer, I. A., Sitabkha, L. \& Pandy, M. (1984). Isolation and prelimnary characterization of proteoglycan aggregates from cultured dermal fibroblasts. F. biol. Chem. 259, 2321-2330.

Shinomura, T., Kimata, K., Oike, Y., Noro, A., Hirose, N., TANABE, K. \& SUzUki, S. (1983). The occurrence of three different proteoglycan species in chick embryo cartilage. Isolation and characterization of a second protcoglycan (PG-Lb) and its precursor form. 7. biol. Chem. 258, 9314-9322.

Siegel, J. N., Malemud, C. J. \& Kammer, G. M. (1987). Intact proteoglycan is a polyclonal activator of murinc B-lymphocytes. Immun. Lett. 15, 127-131.

Sorrell, J. M., Mahmoodian, F. \& Caterson, B. (1988). Immunochemical characterization and ultrastructural localization of chondrotin sulfates and keratan sulfate in embryonic chick marrow. Cell Tiss. Res. 252, 523-531.

SorRell, J. M., VoCI, M. \& Weiss, L. (1987). Ultrastructural localization of heparan sulfate and chondroitin sulfates associated with granulopoiesis in embryonic chick bone marrow. Am. Y. Anat 179, 186-197.

Spooncer, E., Gallagher, J. T., Krizsa, F. \& Dexter, T. M. (1983). Regulation of haemopoiesis in long-term bone marrow cultures. IV. Glycosaminoglycan synthesis and the stımulation of haemoporesis by $\beta$-D-xylosides. F. Cell Biol. 96, 510-514.

Stevens, J. WV., Oike, Y., Handley, C., Hascall, V. C. Hampton, A. \& Caterson, B. (1984). Characteristics of the corc proten of the aggregating proteoglycan from the swarm rat chondrosarcoma. F. cell. Biochem. 26, 247-259.

Sundarra, N., Chao, J., Gregory, J. D. \& Damle, S. P. (1986). Ocular distribution of keratan sulfates during pre- and postnatal development in rabbits. F. Histochem. Cytochem. 34, 971-976. 
TANIGUCHI, N., OKUDA, N. \& NANBA, I. (1974). Characterization of glycosaminoglycans in rabbit plasma and leukocytes at disaccharide subunit level. Biochem biophys. Acta 354, 130-i38.

Trentin, J. J. (1978). Hemopoietic meroenvironments. Transplanth Proc. 10, 77-82.

VASAN, N. S. \& LASH, J. W. (1978). Proteoglycan heterogeneity in cmbryonic chick articular and epiphyscal carttlages. Comm. Tiss. Res. 6, 191-199.

Vlodavsky, I., Falkman, J., Sullivan, R., Fridman, R., IshalMichaeli, R., Sasse, J. \& Klagsbrun, M. (1987). Endothelial cell-derived basic fibroblastic growth factor: synthesis and deposition into subendothelial extracellular matrix. Proc. naln. Acad. Sci. L'.SA. 84, 2292-2296.

Wagner, H. D., Rowe, H. A. \& Connor, J. R. (1983).

Biochemical characteristics of dissociatively isolated aortic proteoglycans and their binding capacity to hyaluronic acid. $\mathcal{F}$. bol.
Chem. 258, 11136-11142.

Wight, T. N., Kinsella, M. G., Keating, A. \& Singer, J. W. (1986). Proteoglycans in human long-term bone marrow cultures biochemical and ultrastructural analyses. Blood 67, 1333-1343.

Williams, N., Jackson, H. \& Rabellino, E. M. (1977). Proliferatson and differentiation of normal granulopostic cells in continuous bone marrow cultures. 7. cell. Plysiol. 93, 435-440.

Ziporı, D., Toledo, J. \& von der MARK, K. (1985). Phenotypic heterogeneity among stromal cell lines from mouse bone marrow disclosed in their extracellular matrix composition and interactions with normal and leukemic cells. Blood 66, 447-455.

ZUCKERMAN, K. S. \& WICHA, M. S. (1983). Extracellular matrix production by the adherent cells on long-tern murine bone marrow cultures. Blood 61, 540-547.

(Received 27 Jamuany 1986 - Accepted, in reqused fom, 2 Jome 1988) 